\title{
Numerical Optimization of Large Shade Sail Support
}

Jakub Javorik

Faculty of Technology, Tomas Bata University in Zlín, Vavrečkova 275, 76272 Zlín, Czech Republic. E-mail: javorik@ft.utb.cz

To design an optimal support of a large shade sail it is necessary to determine forces in wire ropes that support the sail. Relations between a sail loading and ropes reaction forces, rope diameters and sail stresses were investigated. To simulate the sail behavior and set up these relations, numerical (FEM) models were created and analyzed. Most of the results show nonlinear relations between above mentioned parameters and they depend on the sail geometry, applied loads and the rope diameter. It means that for every specific geometry and loading of particular sail an optimal rope diameter and support should be designed. The nonlinear numerical analysis is very suitable tool for this purpose and thus specialized systems based on the Finite Element Method (FEM) should be used to simulate and analyze such problems.

Keywords: Awnings, Numerical Model, Sail, Shade Sail, Wire Rope

\section{References}

[1] JUANICÓ, L. E. (2009). A new design of configurable solar awning for managing cooling and heating loads. In: Energy and Buildings. Vol. 41, No. 12, pp. 1381 - 1385. Elsevier BV.

[2] BRODERICK, R. (2003). The arts of fabric. In: Fabric Architecture. Vol. 15, No. 2, pp. 46 - 50. Industrial Fabrics Association International. Minnesota.

[3] EILAM, I. (2006). An awning on every home. In: Industrial Fabric Products Review. Vol. 91, No. 4, pp. 20 - 26. Industrial Fabrics Association International. Minnesota.

[4] YIMIN, L., JIE, W. (2014). Design and calculation of multi-angel and stepping transmission of sucker rod forging. In: Manufacturing Technology. Vol. 14, No. 4, pp. 650 - 657. Univerzita J. E. Purkyne. Czech Republic.

[5] RUSNAKOVA, S., FOJTL, L., ZALUDEK, M., RUSNAK, V. (2014). Design of material composition and technology verification for composite front end cabs. In: Manufacturing Technology. Vol. 14, No. 4, pp. $607-611$. Univerzita J. E. Purkyne. Czech Republic.

[6] JAVORIK, J. (2014). Simulation and Numerical Analysis of Pneumatic Actuator Behavior. In: International Journal of Mathematics and Computers in Simulation. Vol. 8, No. 1, pp. 189 - 196. North Atlantic University Union. Oregon.

[7] SAMEK, D., JAVORIK, J. (2013). Numerical analysis of shape stability of rubber boot. In: International Journal of Mechanics. Vol. 7, No. 1, pp. 293 - 301. North Atlantic University Union. Oregon.

[8] ŽMINDÁK, M., MĚŠKO, J., PELAGIČ, Z., ZRAK, A. (2014). Finite element analysis of crack growth in pipelines. In: Manufacturing Technology. Vol. 14, No. 1, pp. 116 - 122. Univerzita J. E. Purkyne. Czech Republic.

[9] DELYOVÁ, I., HRONCOVÁ, D., FRANKOVSKÝ, P. (2014). Analysis of simple mechanism using MSC Adams. In: Manufacturing Technology. Vol. 14, No. 2, pp. 141 - 145. Univerzita J. E. Purkyne. Czech Republic.

[10] JAVORIK, J., BILEK, O. (2014). Numerical analysis of bushing of car stabilizer. In: International Journal of Mechanics. Vol. 8, No. 1, pp. 289 - 297. North Atlantic University Union. Oregon.

[11] JAVORIK, J., STANEK, M. (2011). The shape optimization of the pneumatic valve diaphragms. In: International Journal of Mathematics and Computers in Simulation. Vol. 5, No. 4, pp. 361 - 369. North Atlantic University Union. Oregon.

[12] Creative Commons licensed picture Blue aerodynamic modern awnings from author Wonderlane is available at https://www.flickr.com/photos/wonderlane/4648749377/in/photostream/ and is licensed under the CC BY 2.0 license, terms and conditions are available at https://creativecommons.org/licenses/by/2.0/.

[13] TAYYAR, A. E., ALAN, G. (2015). Outdoor usage performances of woven fabrics dyed with self-cleaning dyes. In: Journal of the Textile Institute. Vol. 106, No. 3, pp. 303 - 310. Taylor and Francis Ltd.

[14] FEYRER, K. (2007). Wire Ropes, Tension, Endurance, Reliability. Springer, Berlin, Heidelberg, New York. 